\title{
Exergy as an Indicator for enhancing Evaluation of Environmental Management Performance in the Hospitality Industry
}

\begin{abstract}
The importance of investigating both energy and exergy flows for assessing the environmental profile of buildings has long been acknowledged. Nevertheless, although an ample number of standalone case studies have performed energy analyses in the hospitality industry, empirical studies focusing on exergy are scarce. Extending this line of research, the present study aims to exemplify the conduct of exergy analyses alongside energy ones in optimising environmental management intelligence and improving decision making processes in hospitality accommodation. In doing so, hotels located in international tourism destinations, where tourism has a significant economic impact on the respective countries' Gross Domestic Product (GDP), participated in the study. Energy data from two hotels situated in the Dominican Republic and, from two hotel units located in Greece was collected and analysed in a comparative manner. Findings revealed that energy flows and energy efficiency alone are not sufficient for a comprehensive assessment of hotels' energy profiles. Thus, it is suggested that corresponding exergy flows and efficiency rates should also be estimated along with the energy ones. This study infers that location and hotel star rating classification do not seem to be key parameters in assessing lodgings' energy quality profiles, which suggests the need for further research. The practical implications for hotel managers are also discussed.
\end{abstract}

Keywords: energy; exergy; efficiency; hotels; hospitality industry; environmental management 


\section{Introduction}

Tourism is recognised as a major catalyst for the economic growth and well-being of many countries around the world (Dwyer et al., 2009; Pratt, 2015). Tourism services, such as hospitality and associated activities, form an important part of the global services industry (Sørensen and Jensen, 2015; Tang and Tan, 2015). The significance of tourism and hospitality is even more vital for the national economies of Caribbean and Mediterranean countries (e.g. The Dominican Republic and Greece), propelled by their exceptional landscape characteristics and climatic conditions (Croes, 2006). Going one step further, researchers have recently shown that the tourism and hospitality industry can be practically developed in a sustainable manner, resulting in economic viability of the tourism-related organisations, ecological sustainability and societal responsibility simultaneously (Kozak et al., 2018; Law et al., 2016; Pulido-Fernández et al., 2015).

Hotels are a central feature of the accommodation industry, contributing significantly to regional economies and local communities by generating both revenues and employment (Hadjikakou et al., 2014). From the demand point of view, tourists' selection of accommodation depends heavily on their subjective image of the hotel amenities provided in conjunction with the affordability of the accommodation options offered (Sohrabi et al., 2012).

Yet several researchers have postulated that an increasing number of tourists consider hotels' environmental profiles as an important criterion for selecting accommodation (Høyer, 2000, Carmona-Moreno et al., 2004), in addition to economic and locationrelated criteria. In fact, there is a strong indication that for some tourist segments, accommodation preferences are influenced by hotels' levels of engagement with eco- 
friendly strategies and respective practices (Choi et al., 2009; Millar et al., 2012). This has led many hotel administrations to utilise active and passive energy systems, as well as employ sustainable practices, in order to meet environmental laws and regulations (Simancas Cruz et al., 2018), build a beyond-compliance leadership (e.g. adopting environmental management standards such as ISO14001), and respond to the growing guests' demand for natural resource conservation (Gikas and Tchobanoglous, 2009), waste minimisation (Tan et al., 2017) and energy usage efficiency (Becken and Patterson, 2006; Claver-Cortés et al., 2007). Thus, examining the overall energy profile of hotels is not only a matter of minimising operating costs, but may also function as leverage for attracting specific groups of hotel guests (Pirani and Arafat, 2014).

Nevertheless, up until now, the majority of publications regarding energy consumption and efficiency in the hospitality industry are case studies focusing on energy consumption and performance of hospitality units (e.g. AlFaris et al., 2016; Bohdanowicz and Martinac, 2007; Oluseyi et al., 2016; Priyadarsini et al., 2009), with most of these studies operationalising energy analyses and estimating energy use intensity (EUI). A few researchers have also quantified greenhouse gas (GHG) emissions released from energy consumption and usage using various frameworks, such as a Life Cycle Energy Analysis and regression-based benchmarking predictive models (Filimonau et al., 2011; Huang et al., 2015; Xuchao et al., 2010). Some very interesting conclusions have been extracted from these case studies which show that hotel rating and amenities offered, as well as systems and auxiliary services, have a significant impact on evaluating hotels' environmental profiles. Still, it has been argued that energy efficiency analysis does not suffice in order to evaluate the overall energy potential of the systems installed, because this type of analysis is conducted solely by estimating the amounts of energy wasted during hotel operations compared to the energy inputs; in this case, exergy is the 
proposed property of thermodynamics to be used (Goncalves et al., 2012; Xydis et al., 2009).

Extending this line of thinking, the present study seeks to investigate not only the energy efficiency of lodgings, but also to determine the overall efficiency of the processes and operations utilised in hotels by taking into consideration the quality of energy resources used. This approach indicates that in addition to examining energy efficiency, the exergy efficiency should also be evaluated, serving as an advanced benchmarking criterion in the assessment of environmental performance of hotel units. The premise is that exergy efficiency analysis can actually estimate the utilisable energy at hotels, pertaining to the energy forms utilised.

In fact, although exergy efficiency analysis is well known to engineers, it has not been implemented in the managerial field nor, particularly, in the hospitality/hotel sector. From all previous literature mentioned above, it seems that an enhanced mechanism for evaluating the real energy resource potential that would allow more efficient operations, improved resource management, and enhanced justification of future investments in the hospitality sector is still under investigation. Therefore, we aim to emphasise the use of exergy as an important element of reporting and decision making with respect to resource usage in addition to energy, as it shows the real potential of energy systems installed, and thus any service improvements planned could be made on a much more reliable basis. Consequently, hoteliers and managers would be able to identify areas of improving the energy quality profile of their lodgings and enhance sustainable (i.e. economic and environmental) decision making in this industry (Fotiadis et al., 2013).

Moreover, it has been recognised that hotel location may considerably influence exergy estimates due to different properties of system surroundings, reference temperatures, as well as due to energy mix differences between countries (Hermann, 
2006; Torio et al., 2009). Therefore, this research adopts an international perspective, conducting comparative energy and exergy efficiency analyses; this is implemented by using primary data from hotels located in the Dominican Republic, which are then compared and benchmarked with recently validated data coming from hotels operating in Greece.

Additionally, some studies suggest that a hotel's star rating classification may be an important parameter when examining hotels' engagement with efficient and effective energy usage (Mensah, 2006). For example, it has been reported that one-star-hotel administrations are, in general, little interested in adopting energy efficient practices to improve hotels' overall environmental profile; yet, some researchers (Ali et al., 2008; Cipriano and Jafari, 2002) indicate that higher star-rated hotels seem to be more inclined towards reducing energy consumption and waste production deriving from hotel services, whereas others (El Dief and Font, 2012; Stylos and Vassiliadis, 2015) concluded that hotel rating classification may not play a significant role in the perceived importance and actual implementation of ecological-related practices. Hence, comparisons in this study are performed between selected three-star and five-star hotels located in the Dominican Republic and Greece, respectively, considering their energy and exergy efficiency of their operations.

This research makes important contributions to the area of energy resource management within a hospitality industry context. First, it highlights the need for estimating both energy and exergy efficiencies to better determine the energy quality profile of tourist lodgings, by utilising a thermodynamics theoretical framework and showcasing the managerial aspect of the topic. Second, it takes into account the star rating classification of the tourism accommodations while employing energy and exergy analyses, thus responding to the call of Filimonau et al. (2011) for comparative research 
between hotels of different star rating. Third, the current research runs energy and exergy analyses following a multiple case study approach and based on a diverse geographic outlook, considering the relevant research call of Teng et al. (2012) for future transnational studies in the area.

Overall, this research attempts to encapsulate both the engineering and managerial perspectives of utilizing energy resources efficiently and effectively. It proposes that the knowledge area of exergy analysis and respective indicators should be integrated in the managerial practices to improve the report and control of energy resources consumption, and further evolve to support sustainability in the hospitality industry. Theoretically the study makes an important step in employing an energy engineering-based analysis to improve energy management in the hospitality industry. From a practical viewpoint, it draws attention to the importance of considering the energy quality profile of hotels (i.e. exergy) in the study of ecological impact, as well as in energy saving and environmental decision making as part of hotel administrations' sustainability agenda.

\section{Materials and methods}

\subsection{Energy and exergy analyses}

Energy and carbon balances comprise a very important aspect of the environmental sustainability of a human-made system (Slade and Bauen, 2013). In general, when assessing the energy balances of designed systems, all forms of energy are regarded as equivalent, without differentiating between the different grades of energy crossing the system boundaries (Kotas, 2013). To be specific, energy balances do not provide any specific information about the amount of internal losses (Kharrazi et al. 2014). Hence, to overcome this limitation of energy balances, exergy analysis (EA) has been developed (Meyer et al. 2009; Peralta-Ruiz et al. 2013). It is a methodology based on the principle 
of energy preservation (first thermodynamic law), as well as the principle of entropy destruction (second thermodynamic law) attempting to analyse, design, and improve energy systems reporting (Granovskii et al. 2008; Torio et al., 2009). EA may reveal the parts and/or activities of a system where the work potential, provided via natural resources (e.g. fuels and raw materials), is not efficiently exploited. Hence, implementation of EA may indicate areas where efficiency benefits may be obtained (Koroneos \& Stylos, 2014; Rosen et al. 2008) or/and the use of relevant energy carriers may be replaced by more exergy efficient ones. In all, EA is used to perform more meaningful comparisons between systems and draw conclusions regarding their energy and environmental profile.

\subsection{Energy and Exergy efficiencies}

Exergy is defined as a universal measure of the work potential or quality of different forms of energy in relation to a given environment (Goncalves et al., 2012; Romero and Linares, 2014). As Chow et al. (2009) explain "exergy is simply the available energy obtained by subtracting the unavailable energy from the total energy and is equivalent to the work transformable. The loss of exergy, or irreversibility, provides a generally applicable quantitative measure of process inefficiency (Kotas, 2013).

The exergy balance is similar to an energy balance, although it has the fundamental difference that, while the energy balance is a statement of the law of conservation of energy, the exergy balance may be looked upon as a statement of the law of degradation of energy. Degradation of energy is equivalent to the irreversibility loss of exergy due to all real processes being irreversible (Dincer and Rosen, 2005; Kotas, 2013). 
From a technical point of view, exergy is the ability to produce work when brought into equilibrium with the environment (Koroneos and Rovas, 2012). Accordingly, energy efficiency is given as (Xydis et al., 2009):

$\eta_{(\text {energy })}=\frac{\text { work }}{\text { energy } y_{\text {input }}}$

whereas, exergy efficiency is defined as:

$\psi_{(\text {exergy })}=\frac{\text { work }}{\text { exergy }}$

Furthermore, exergy efficiency is the energy efficiency over "exergy factor" ratio:

$\psi=\frac{\eta}{\gamma}$

where:

$\eta=$ energy efficiency,

$\psi=$ exergy efficiency, and

$\gamma=$ exergy factor.

The exergy factors for electricity and diesel oil are 1.00 and 1.07, respectively (Kotas, 2013). Thus, the exergy value of the electricity consumed in electric devices is equal to the corresponding energy value, therefore in this case the exergy efficiency coincides with the energy efficiency.

The typical energy mix used to meet the needs of the chosen hotels in both the Dominican Republic and Greece consists of electricity and diesel oil. Since the energy consumption in hotels depends on the type of hotel, size, construction method, and location (and because of that a comparison with other hotels is not always sufficient), the energy analysis can provide an evaluation of energy efficiency, however the EA can give more information regarding the quality of energy used or in practice it can even be 
measured as the quality of energy wasted (Goodarzvand-Chegini, 2017). EA, as a longterm comparison on year-to-year performance can serve as a yardstick that can be introduced into a wider indicator framework (Kirk, 1995).

Table 1. Energy and exergy average efficiencies for selected resources (Kotas, 2013).

\begin{tabular}{lcc}
\hline & Oil & Electricity \\
\cline { 2 - 3 } Energy efficiency $(\eta)$ & 0.300 & 0.563 \\
Exergy efficiency $(\psi)$ & 0.281 & 0.563 \\
\hline
\end{tabular}

Furthermore, the energy and exergy average efficiencies for Oil and Electricity are provided on Table 1. It clearly shows that exergy efficiencies are lower or equal to the energy efficiencies, due to the destruction of the input exergy caused by irreversibilities (Saidur et al., 2007). In fact, the main concern in energy efficiency is to minimise energy losses, whereas in exergy efficiency the focus is on system performance improvement by taking into account not only the losses, but also the internal irreversibilities (Dincer, Hussain, \& Al-Zaharnah, 2004).

Next, energy and exergy flows, and corresponding efficiencies of four hotels located in the Dominican Republic and Greece will be evaluated following a multiple case study approach.

\section{Case study}

The two countries, the respective local tourism destinations and hotels, in particular, have been selected on the basis of some common characteristics in order to allow for meaningful comparisons. To mention just a few shared features, in both the Dominican Republic and Greece tourism and hospitality form a key national industry pillar, the sun and sand tourist product is dominant, and electricity generation depends heavily on fossil fuels. However, there are some differences in the climatic conditions, national energy 
mixes and economic structures of the two countries that could potentially affect the hotels' energy consumptions. In regard to the hotels participating in this study, the selection was made based on the types of main amenities listed and their reported occupancy rates ( $85 \%$ for each hotel on the 8 -month cycle between March and October). Although all four hotels selected have similar energy systems installed, the amount of equipment used depends on rooms capacity, number of buildings and hotels' star-ratings (Tables 2 and 3). In addition to the main hotel characteristics, all four hotels hold an energy efficiency rating of grade $\mathrm{C}$, there are central systems for ventilation and airconditioning that are centrally controlled, all rooms have blinds and lighting is provided by compact fluorescent (CFL) bulbs and LED tubes. Food services are provided by one kitchen at both $3^{*}$ hotels and five kitchens at the $5^{*}$ hotels, which correspond to the number of restaurants available. Hot water is fully covered by solar water heater systems as solar irradiation is abundant in both the Dominican Republic and Greece and there is no need for auxiliary heating systems. Lifts are also installed to support guest services and their number varies depending on the architecture and the needs of each hotel unit, for example there is an elevator that links Grand Principe Cayacoa down to the beach (see table 4).

Notwithstanding the influence of globalisation, there are some dissimilarities in the energy systems supporting hotel operations and the environmental practices implemented on behalf of the hotel administrations within, although all hotels participating in the study apply energy saving policies. It would be therefore quite interesting to investigate the energy profiles of the selected hotel units. To do so, we selected hotels of different starratings located at different geographic regions and then compared the findings resulting from energy analyses with those emerging from the exergy ones. 
The isle of Crete and the Chalkidiki peninsula are two international tourism destinations located in southern and northern Greece, respectively. Their mild climatic conditions and beautiful Mediterranean landscapes and coasts attract millions of tourists from around the world. The hospitality sector is well developed in both locations with a wide range of accommodation services offered by units of different star rating (PérezPineda et al., 2017; Pappas, 2015). The majority of lodgings have been awarded three to five stars ratings depending on amenities provided. Although Crete and Chalkidiki have a global destination outlook and tourism follows an impressive growth pattern, the hospitality sector still operates on an 8-month annual cycle at both locations.

Samaná is a peninsula located in the northeast region of the Dominican Republic and one of the main tourism destinations of the country (see Figure 1). Humpback whale watching is one of the major attractions in winter and spring seasons. It is a mountainous area and characterised by its humid and coconut planted territory. As expected for a world leading tourism destination, the hospitality sector is well developed on the Samaná peninsula with various lodgings, supporting structures and resorts being in place to serve tourists' diverse accommodation needs. The majority of the lodgings available in Samaná have a three to five-star rating.

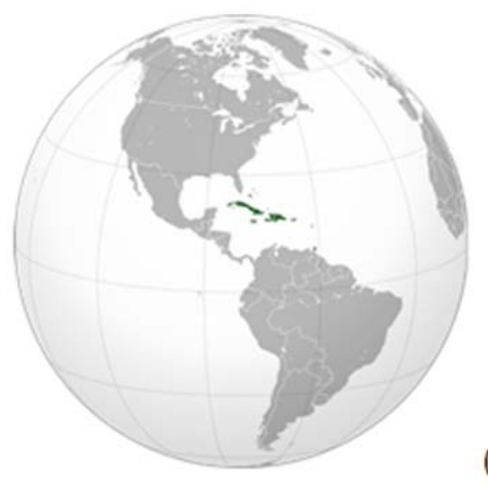

(a)

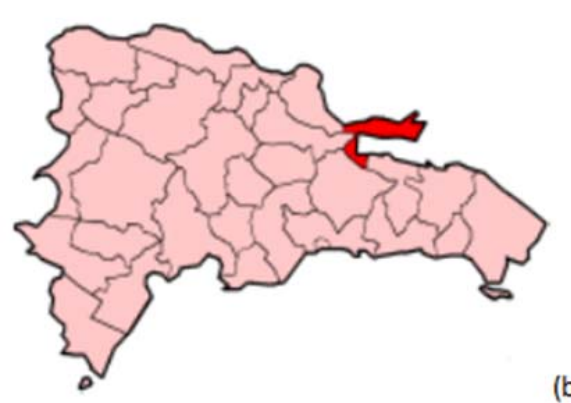

Figure 1. Caribbean zone map and Samaná region highlighted on the Dominican Republic's map. 


\subsection{Gran Bahía Principe Cayacoa and La Tambora Hotels}

Gran Bahía Príncipe Hotel is a five-star hotel located at 70km from El Catey International Airport and 15km from Arroyo Barril International Airport (see Figure 2). La Tambora hotel is a three-star hotel located in Los Cacaos, Las Galeras, and fifteen minutes away from Samaná city (see Figure 3). Table 2 summarises the amenities of both hotels.

This research draws on energy data regarding the main operations and processes for the particular hotels. The energy consumption (electricity and heating) at Cayacoa and La Tambora hotels for the year 2016 is presented on Figures 4 and 5, respectively. As one may notice, electricity represents the major energy source utilised throughout the year at Cayacoa hotel, whereas, diesel is mainly used to cover the needs in energy at La Tambora Hotel.

Table 2. Hotel facilities descriptions for the two hotels located in Dominican Republic.

\begin{tabular}{ll}
\hline \multicolumn{1}{c}{ La Tambora 3* } & Gran Bahía Príncipe Cayacoa 5* \\
\hline 60 rooms capacity & 295 rooms capacity \\
$\begin{array}{l}\text { One main reception \& lobby } \\
\text { building and five independent two } \\
\text { floor lodgings }\end{array}$ & $\begin{array}{l}\text { One main building, with all rooms offering sea } \\
\text { view, and fourteen independent smaller } \\
\text { buildings }\end{array}$ \\
$\begin{array}{l}\text { One pool, a restaurant, two bars, } \\
\text { conference rooms, gardens and } \\
\text { outdoor activities (riding bicycle, } \\
\text { snorkeling, fishing) }\end{array}$ & $\begin{array}{l}\text { Three pools, five restaurants, four bars, a } \\
\text { conference/business center, spa, gym, water } \\
\text { activities (Kayaking, windsurfing, diving), land }\end{array}$ \\
All year-round operation & All year-round operation \\
\hline
\end{tabular}



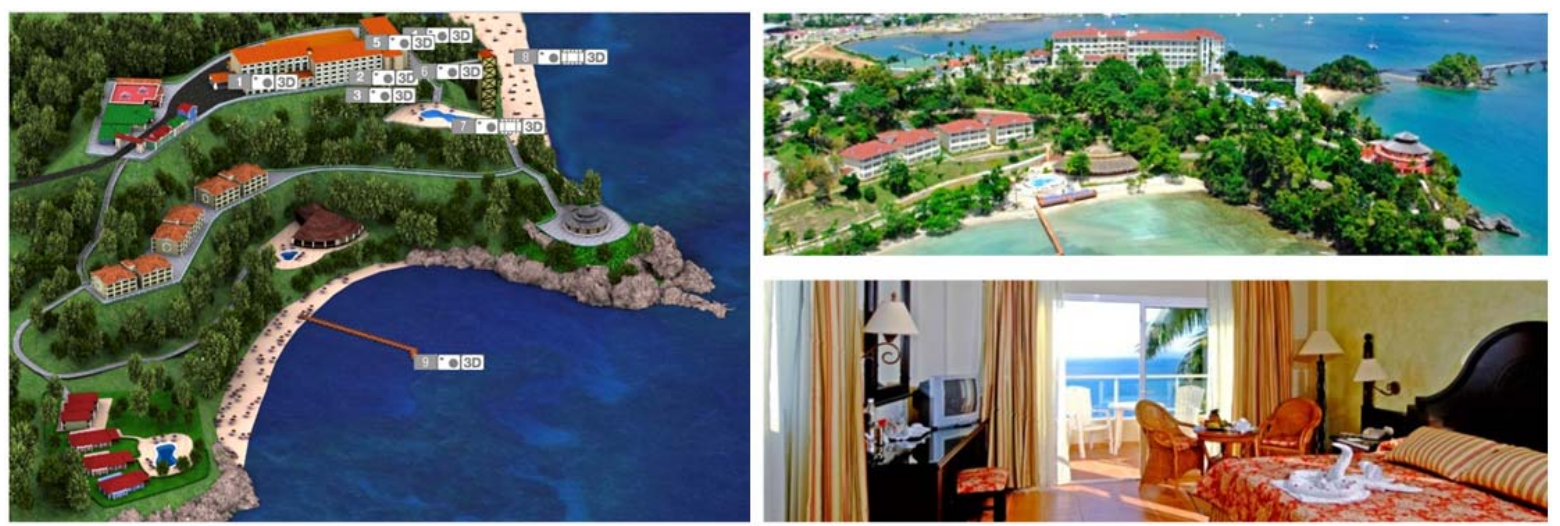

Figure 2. Hotel Gran Bahía Principe site map and room distribution (Samaná, Dominican Republic).

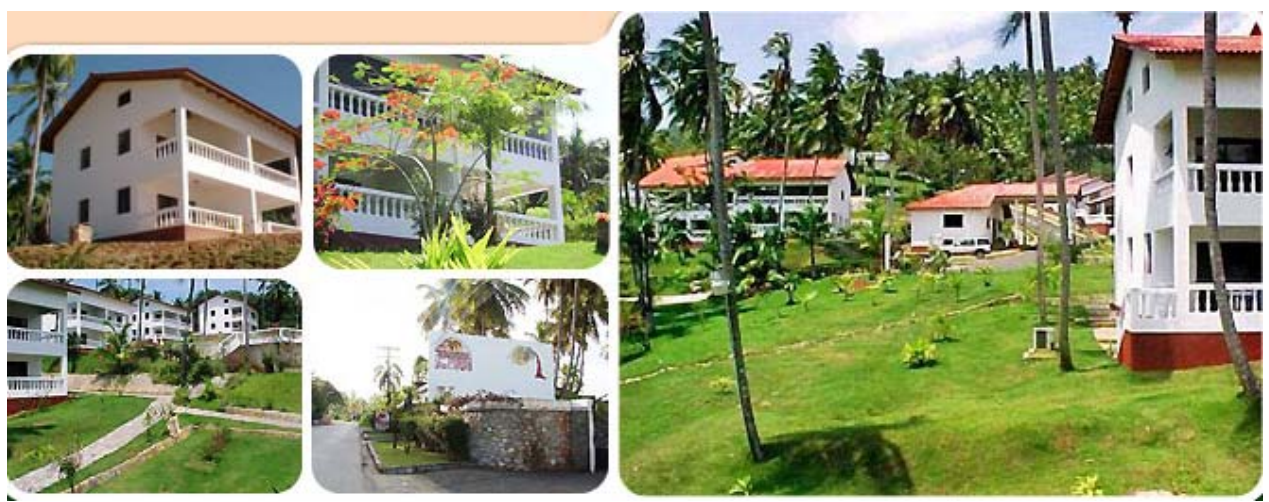

Figure 3. La Tambora hotel premises (Samaná, Dominican Republic). 


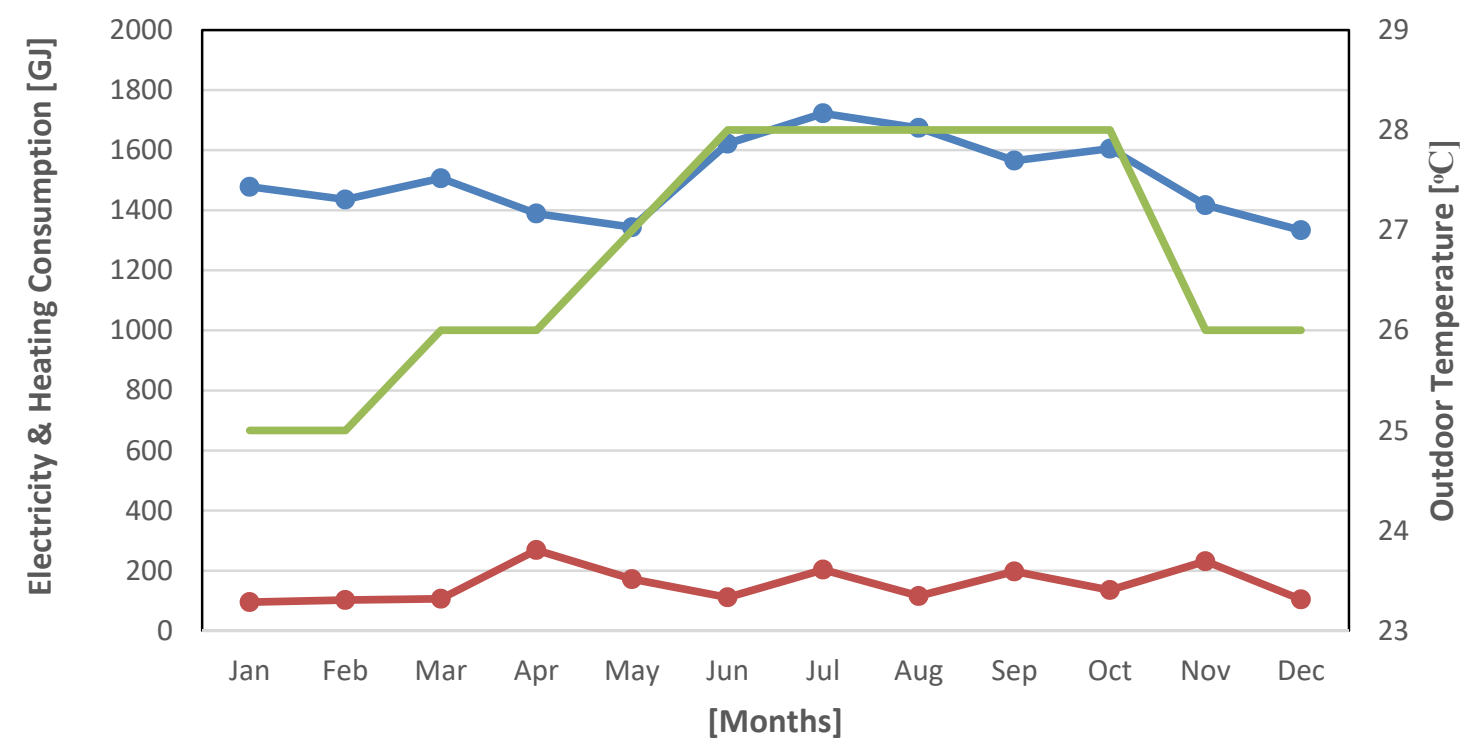

$\longrightarrow$ Electricity $\longrightarrow$ Diesel oil $\longrightarrow$ Outdoor temperature

Figure 4. Electricity and diesel oil consumption in Cayacoa Hotel (year 2016).

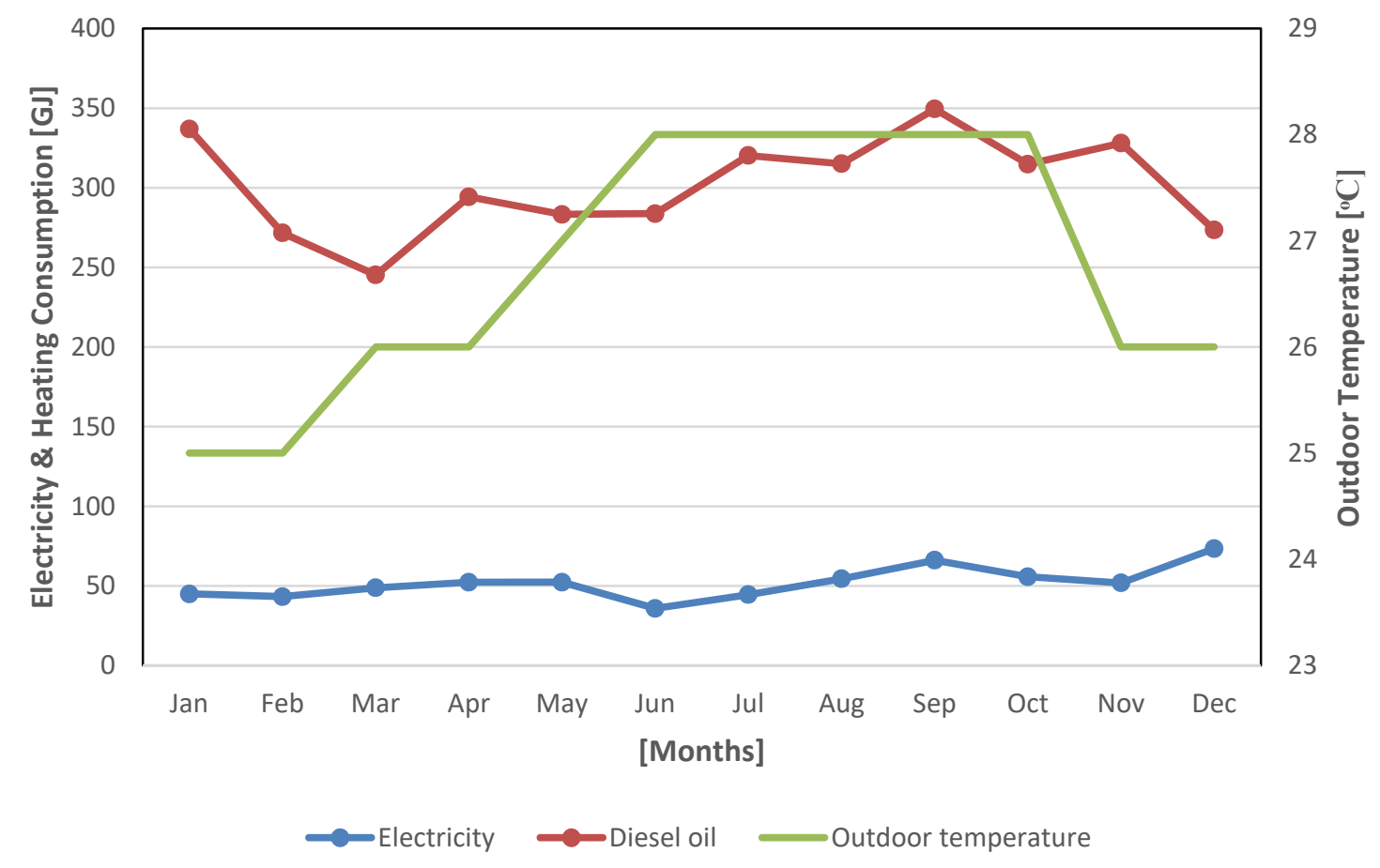

Figure 5. Electricity and diesel oil consumption in La Tambora Hotel (year 2016).

\subsection{Rethymno hotel \& Kassandra hotel complex}


Two hotels operating in Greece were chosen to serve as reference and benchmark cases for the energy and exergy evaluation of the hotels located in the Dominican Republic. The selected three-star and five-star hotels are located in Crete and Chalkidiki, respectively (see Figure 6). The energy and exergy profiles of Rethymno and Kassandra hotels were previously investigated by Xydis and his colleagues (2009), and their study offers a good basis for possibly extending the arguments made to support utilisation of exergy efficiency analysis.

The lodging in Rethymno has a total capacity of 140 rooms with all of them offered in a single building, whereas the Kassandra hotel complex offers 500 rooms in three different accommodation establishments located on a beautiful promontory. Table 3 provides details of the Greek hotel premises.

Regarding the energy consumption at the selected hotels located in Greece, the data provided by the hoteliers covers 2016 on a year-round basis, although the actual operational period is 8 months long only. From November to February, the Greek hotels are not open to the public, however the energy systems installed in both of them function on a standby basis covering very limited administration and maintenance-related power needs (see Figures 7 and 8). The total annual energy consumption in the Rethymno hotel is almost the same as in previous years with only slight variations. This is probably due to offering accommodation solely to organised group travellers throughout the operating season and reservations and overall occupancy rates have remained stable over the last few years. Furthermore, the monthly energy consumption is close but, of course, not equal to the 2002 data (Xydis et al., 2009). While revising the manuscript, we contacted Rethymno hotel for additional explanations about the obvious similarity of the annual energy consumption between years 2002 and 2016. The main point was that although the totals are almost the same, the monthly consumptions vary based on the distribution of 
reservations, with the variations being small; all rooms in July and August are almost $100 \%$ packed and there are only some small differences between March - June and September - October.

Similarly, the variations in energy consumption for the Kassandra hotel are very small, i.e. up to $2 \%$ higher in total during the last decade. Also, hotel guests' consumption patterns have largely remained unchanged, as hoteliers target on same inbound tourist populations over the last years.

On the other hand, although annual energy consumptions at these hotels was kept at similar levels, the cost of both electricity and products of petroleum has almost doubled in Greece during the last decade.

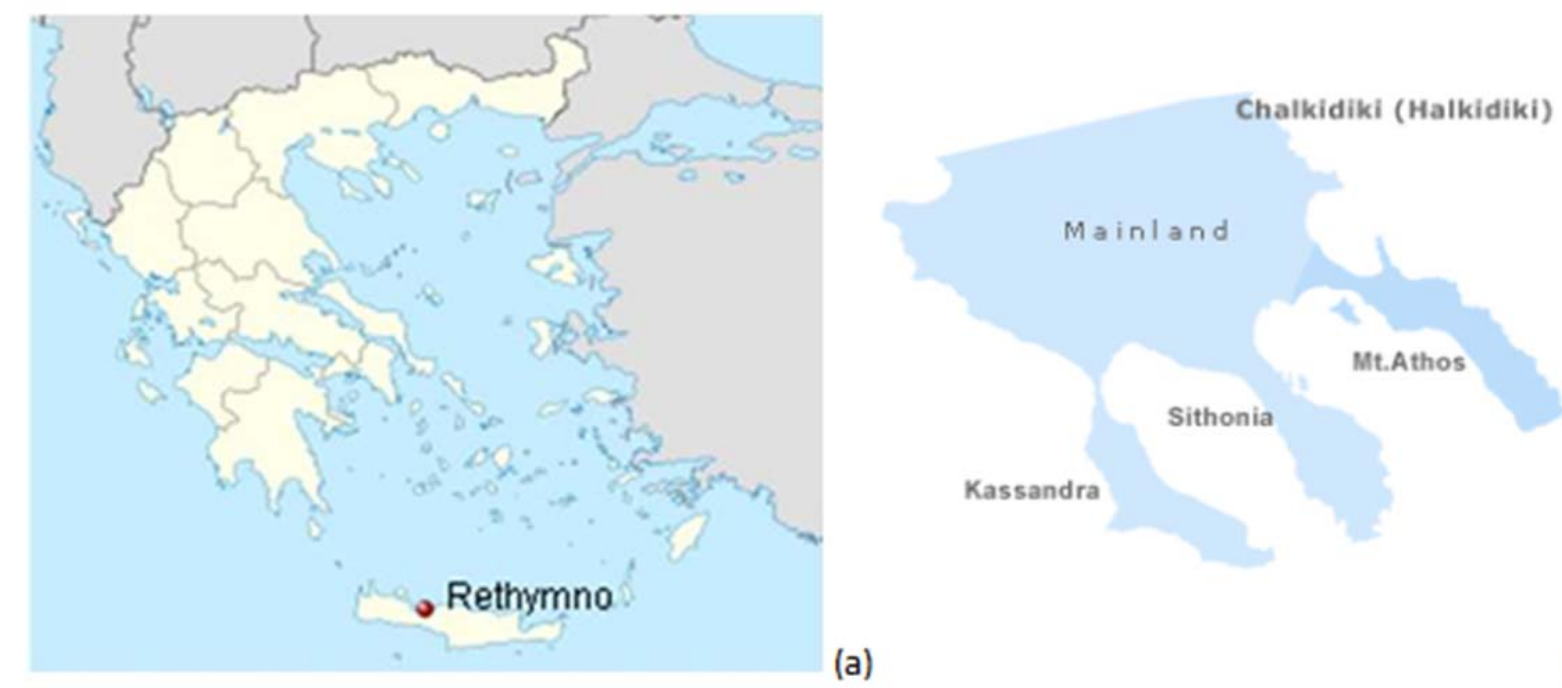

Figure 6. Rethymno (Crete) and Kassandra (Chalkidiki) locations in Greece. 
Table 3. Facilities of the hotels located in Greece.

\begin{tabular}{ll}
\hline Rethymno $3 *$ & Kassandra $5 *$ \\
\hline 140 rooms capacity & 500 rooms capacity
\end{tabular}

One main accommodation building and Three different lodgings/units three auxiliary structures comprising one hotel system

One pool, a restaurant, a bar/lounge, Three pools, five restaurants, four bars, business/meeting rooms, gardens and a conference/business center, gym, courts for outdoor activities water activities (windsurfing, kite, sailing), land activities (football, volleyball, tennis)

Power/Heating consumption insignificant Power/Heating consumption during non-operation period insignificant during non-operation period

Operating March through October Operating March through October

Table 4. Main equipment, supporting systems per hotel and energy consumption.

\begin{tabular}{|c|c|c|c|c|c|}
\hline & Unit & Cayacoa & $\begin{array}{c}\text { La } \\
\text { Tambora }\end{array}$ & Rethymno & Kassandra \\
\hline Rooms & - & 295 & 60 & 140 & 500 \\
\hline AC central units & - & 15 & 6 & 1 & 3 \\
\hline Central heating units & - & 5 & 6 & 1 & 3 \\
\hline $\begin{array}{l}\text { Solar water heating } \\
\text { systems }\end{array}$ & - & 3 & 1 & 1 & 1 \\
\hline Lifts & - & 5 & 2 & 2 & 6 \\
\hline Hotel Kitchen sets & - & 5 & 1 & 1 & 5 \\
\hline Avg. outdoor & {$\left[{ }^{\circ} \mathrm{C}\right]-\mathrm{op}$} & 26.75 & 26.75 & 21.01 & 17.33 \\
\hline temperature* & {$\left[{ }^{\circ} \mathrm{C}\right]-8 \mathrm{~m}$} & 27.38 & 27.38 & 24.25 & 22.38 \\
\hline Electricity & {$\left[\mathrm{GJ}_{\mathrm{n}}\right]-\mathrm{op}$} & 18089.86 & 623.38 & 1266.02 & 21459.00 \\
\hline Diesel & {$\left[\mathrm{GJ}_{\mathrm{n}}\right]-\mathrm{op}$} & 1843.85 & 3616.13 & 586.54 & 2443.64 \\
\hline
\end{tabular}

* Averages during the respective operations cycles, i.e. 12 months for Dominican Republic and 8 months for Greece, and then re-estimated to the common 8-month cycle. 


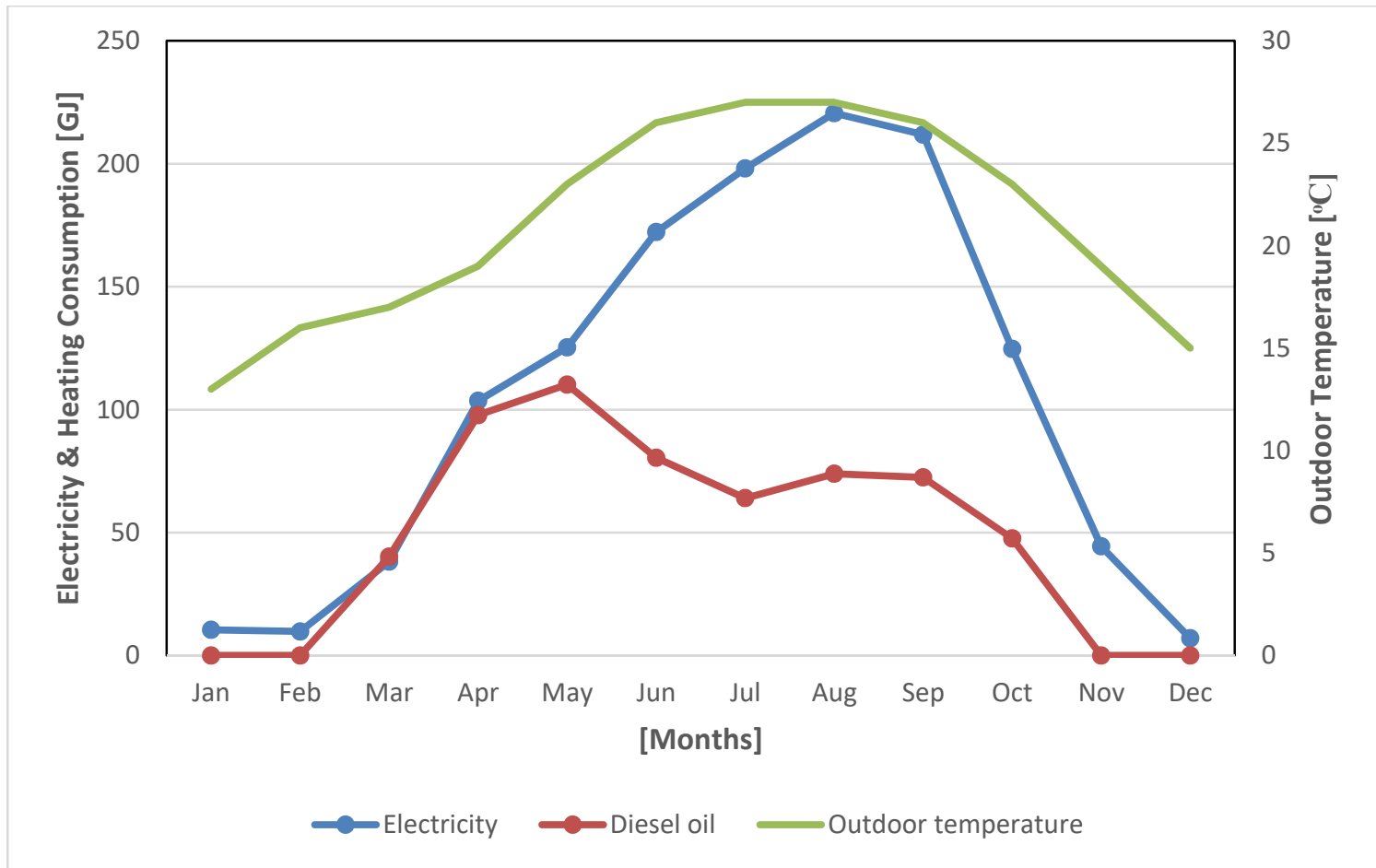

Figure 7. Electricity and diesel oil consumption for Rethymno Hotel (year 2016).

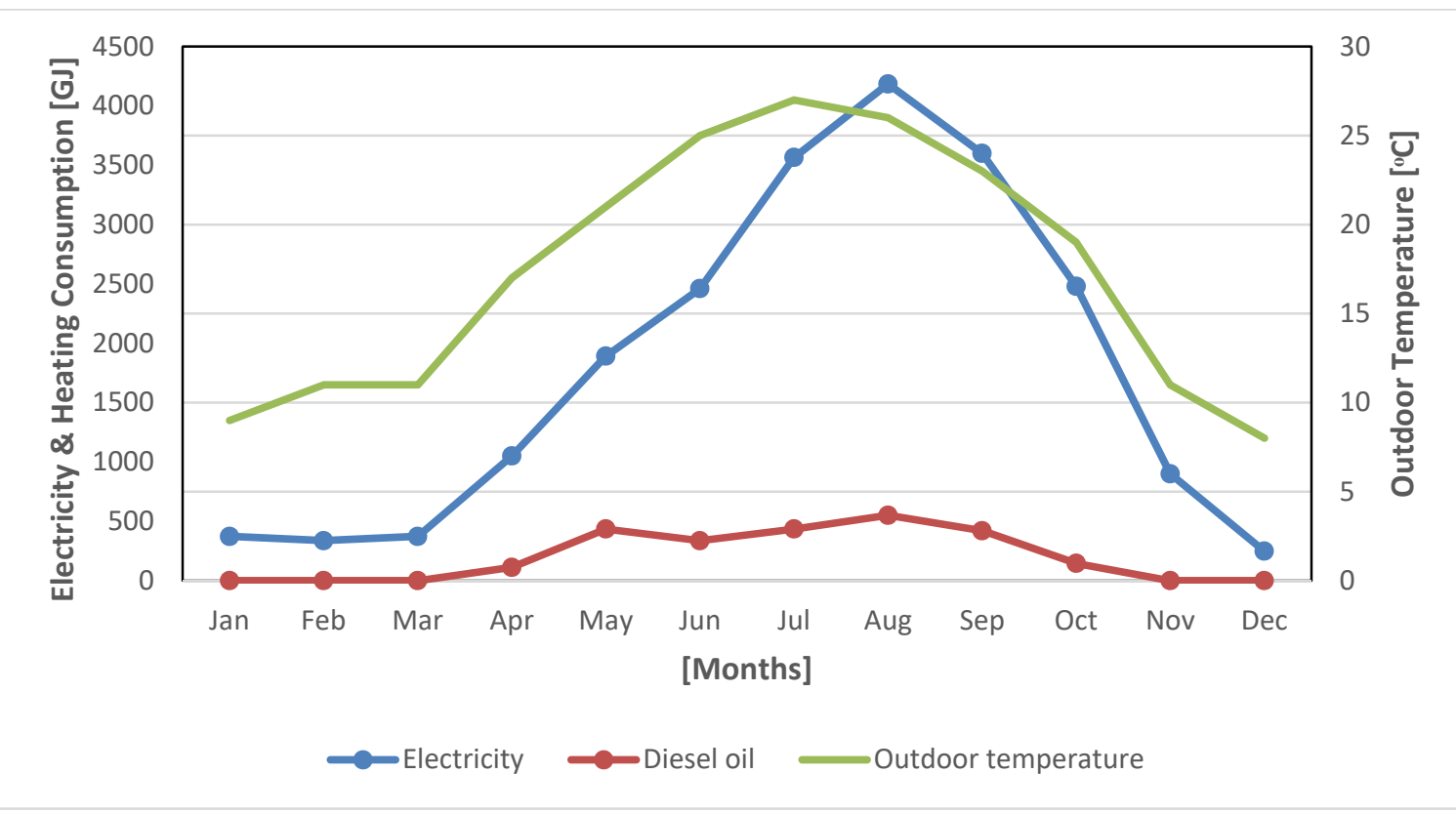

Figure 8. Electricity and diesel oil consumption for Kassandra Hotel (year 2016). 


\section{Results}

\subsection{Energy and exergy flows at hotels}

The energy and exergy flows have been estimated for each hotel participating in this study based on the monthly data provided by the hotel administrations. As Goncalves et al. (2012) postulate, the reference environment state could significantly influence the outcomes of exergy analysis, especially in the case of space heating and cooling of buildings (Torio, Angelotti \& Schmidt, 2009). Concerning the current study, the annual average outdoor temperatures observed in Samaná, Crete and Chalkidiki are $26.75^{\circ} \mathrm{C}$, $21.01{ }^{\circ} \mathrm{C}$ and $17.33{ }^{\circ} \mathrm{C}$, respectively (Holiday Weather.Com, 2017). Also, minimum and maximum temperatures on a monthly basis follow similar patterns with the exception of the period of November to February that becomes much colder at the Greek destinations. However, since these months are excluded from the operational period of the Greek hotels, the temperature averages have smaller differences between March and October (main tourism cycle) in the selected regions, i.e. $27.38^{\circ} \mathrm{C}, 24.25{ }^{\circ} \mathrm{C}$ and $22.38{ }^{\circ} \mathrm{C}$ for Samaná, Crete and Chalkidiki, respectively (see Table 4).

The energy flows are shown on Table 5, with electricity and diesel oil comprising the total energy flows. The monthly energy consumption data have been provided by the hoteliers in excel sheets. Hotel managers monitor energy consumption through: 1) electricity meter readings and diesel oil orders on a monthly basis, and 2) the bi-monthly electricity bills; the bills were not shared with us, as managers did not want to disclose any associated financial data.

Figure 9 demonstrates the exergy flows at each hotel on a monthly basis. It is evident that Kassandra hotel has the largest exergy consumption followed by La Tambora and Cayacoa hotels. Rethymno hotel is the one with the smallest total usable work consumed. 
Figure 10 offers a breakdown of the total exergy flows on per type of exergy source (i.e. electricity and diesel oil), thus allowing for enhanced comparisons among the four hotels under study.

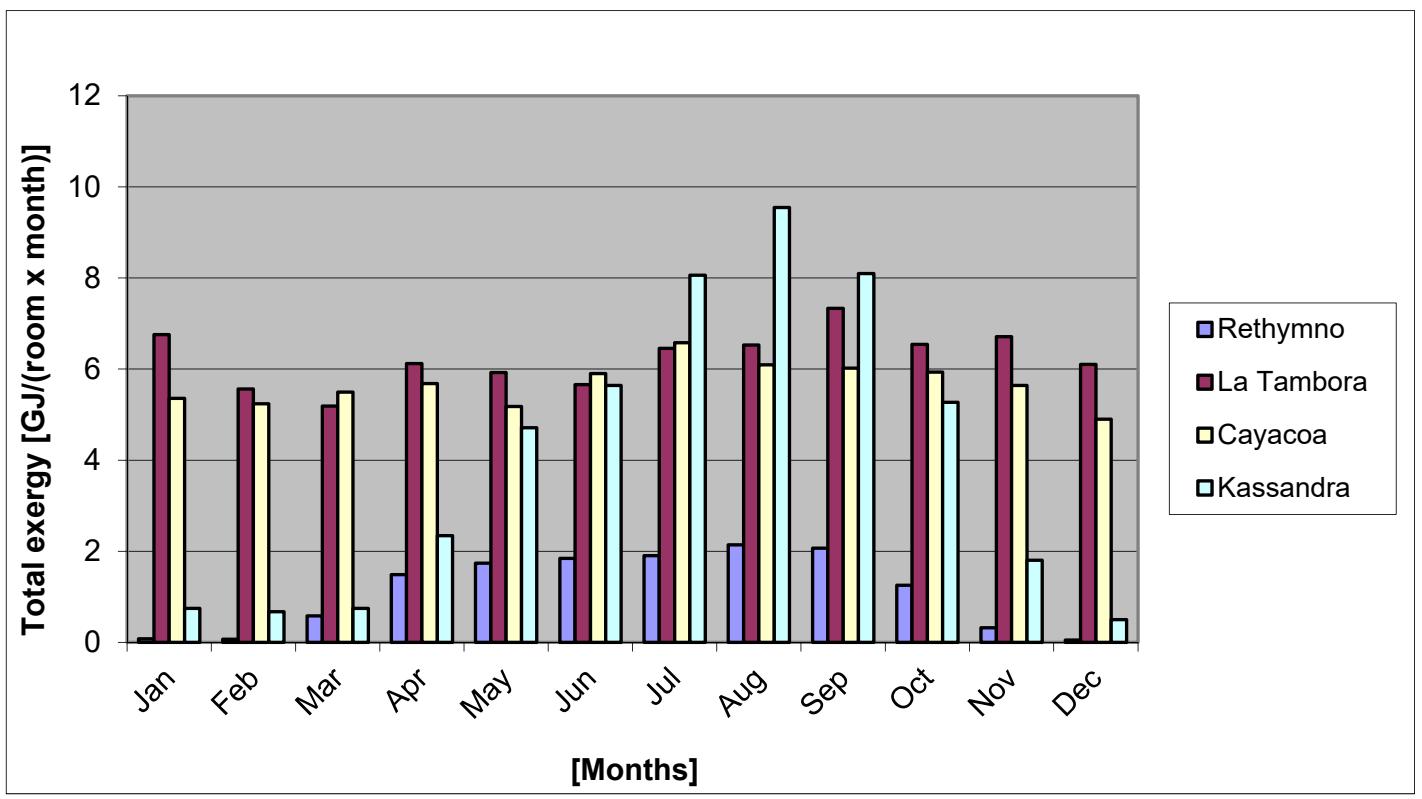

Figure 9. Total exergy per room and month for the four hotels (12 months).

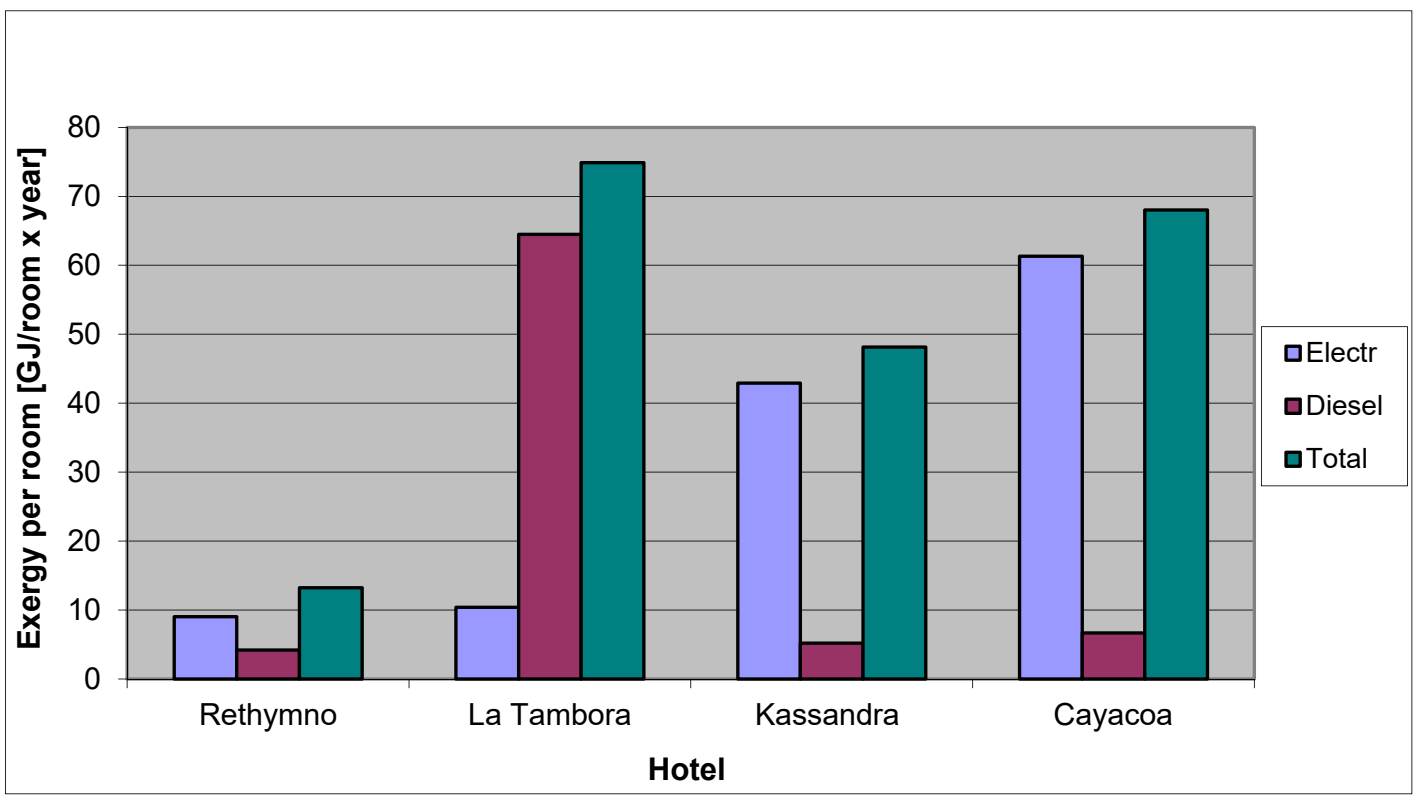

Figure 10. Annual exergy values per room and energy source (12 months). 
Table 5 summarises hotels' consumption of electricity and diesel comprising the total energy used to run their operations. The corresponding exergy values have been derived from the corresponding energy ones multiplied by the exergy factors $\gamma$ for the selected energy sources (equals 1 for electricity and 1.07 for diesel oil, as previously mentioned). Furthermore, Table 5 demonstrates that Kassandra hotel is the one with the largest absolute energy and exergy flows due to its high capacity (65\% higher capacity compared to Cayacoa), although it operates fully for only 8 months per year. On the other hand, Rethymno hotel is the one with the lowest energy needs, although La Tambora hotel is $57 \%$ smaller in room capacity.

However, to compare hotels' energy profiles on a common basis, the energy and exergy flows have been recalculated according to hotels' room capacity and also taking into account the short operational period of Greek hotels ( 8 out of 12 months). This way, the energy and exergy figures of the all four hotels will reflect their true energy profile. As presented on Table 5, the highest annual energy and usable work potential consumed are at La Tambora hotel on a per room basis, with 70.66 and $74.88 \mathrm{GJ} /($ room $\times$ season), respectively. It is worth mentioning that the $5 *$ Cayacoa hotel has lower annual energy and exergy rates than the $3 *$ La Tambora (67.57 and 68.01 vs. 70.66 and 74.88 $\mathrm{GJ} /($ room $\times$ season), respectively), although the first one offers more and higher-level guest services and amenities. The $3 *$ Rethymno hotel is the one with the lowest annual energy and exergy flows per room (18.85 and $20.88 \mathrm{GJ} /($ room $\times$ season $))$. Finally, Kassandra hotel demonstrates the highest normalized energy consumption rate surpassing that of La Tambora ((71.69 vs. $70.66 \mathrm{GJ} /($ room $\times$ season $))$. Nevertheless, the corresponding normalisation for exergy flows reveals that the highest exergy consumption takes place at La Tambora and not Kassandra hotel ( 74.88 vs. 72.20 $\mathrm{GJ} /($ room $\times$ season $))$. 
Table 5. Annual energy and exergy values (electricity, heating and total flows).

Unit Cayacoa La Tambora Rethymno Kassandra

\begin{tabular}{|c|c|c|c|c|c|}
\hline $\begin{array}{l}\text { Number of } \\
\text { Rooms }\end{array}$ & - & 295 & 60 & 140 & 500 \\
\hline $\begin{array}{l}\text { Electricity } \\
\text { (energy) }\end{array}$ & {$\left[\mathrm{GJ}_{\mathrm{n}}\right]$} & 18089.86 & 623.38 & 1266.02 & 21459.00 \\
\hline $\begin{array}{l}\text { Diesel } \\
\text { (energy) }\end{array}$ & {$\left[\mathrm{GJ}_{\mathrm{n}}\right]$} & 1843.85 & 3616.13 & 586.54 & 2443.64 \\
\hline Total Energy & {$\left[\mathrm{GJ}_{\mathrm{n}}\right]$} & 19933.71 & 4239.51 & 1852.56 & 23892.64 \\
\hline $\begin{array}{l}\text { Electricity } \\
\text { Normalized } \\
\text { (energy) }\end{array}$ & {$\left[\mathrm{GJ}_{\mathrm{n}} /(\operatorname{room} \times\right.$ season $\left.)\right]$} & 61.32 & 10.39 & 13.56 & 64.38 \\
\hline $\begin{array}{l}\text { Diesel } \\
\text { Normalized } \\
\text { (energy) }\end{array}$ & {$\left[\mathrm{GJ}_{\mathrm{n}} /(\right.$ room $\times$ season $\left.)\right]$} & 6.25 & 60.27 & 6.28 & 7.31 \\
\hline $\begin{array}{l}\text { Total energy } \\
\text { (normalized) }\end{array}$ & {$\left[\mathrm{GJ}_{\mathrm{n}} /(\right.$ room $\times$ season $\left.)\right]$} & 67.57 & 70.66 & 19.85 & 71.69 \\
\hline $\begin{array}{l}\text { Electricity } \\
\text { (exergy) }\end{array}$ & {$\left[\mathrm{GJ}_{\mathrm{x}}\right]$} & 18089.86 & 623.38 & 1266.02 & 21459.00 \\
\hline $\begin{array}{l}\text { Diesel } \\
\text { (exergy) }\end{array}$ & {$\left[\mathrm{GJ}_{\mathrm{x}}\right]$} & 1973.55 & 3869.40 & 627.20 & 2605.00 \\
\hline Total Exergy & {$\left[\mathrm{GJ}_{\mathrm{x}}\right]$} & 20063.41 & 4492.78 & 1893.22 & 24064.00 \\
\hline $\begin{array}{l}\text { Electricity } \\
\text { Normalized } \\
\text { (exergy) }\end{array}$ & {$\left[\mathrm{GJ}_{\mathrm{x}} /(\right.$ room $\times$ season $\left.)\right]$} & 61.32 & 10.39 & 13.56 & 64.38 \\
\hline $\begin{array}{l}\text { Diesel } \\
\text { Normalized } \\
\text { (exergy) }\end{array}$ & {$\left[\mathrm{GJ}_{\mathrm{x}} /(\right.$ room $\times$ season $\left.)\right]$} & 6.69 & 64.49 & 6.72 & 7.82 \\
\hline $\begin{array}{l}\text { Total Exergy } \\
\text { (normalized) }\end{array}$ & {$\left[\mathrm{GJ}_{\mathrm{x}} /(\right.$ room $\times$ season $\left.)\right]$} & 68.01 & 74.88 & 20.28 & 72.20 \\
\hline
\end{tabular}




\subsection{Energy and exergy efficiencies at hotels}

Based on the energy and exergy flows previously estimated, the corresponding overall energy and exergy efficiencies have also been calculated using formulas (1) - (3) of section 2.2. The results included in Table 6 show that the energy, as well as the exergy efficiency rates of the processes at three out of four hotels (i.e. Cayacoa, Rethymno and Kassandra) are remarkably close to each other. To be specific, the Cayacoa and Kassandra hotels have exactly the same energy efficiency rate (0.562). Rethymno hotel follows closely with an energy efficiency of 0.559 and La Tambora has the lowest rate demonstrating a difference of about $2.3 \%$.

Moreover, the systems supporting operations in the Cayacoa and Kassandra hotels have similar exergy efficiency rates that are quite close to the energy efficiency ones (see Table 6). The two relatively smaller hotels, namely Rethymno and La Tambora, have considerably lower exergy efficiencies than their corresponding energy ones. This is particularly evident with the exergy efficiency of the 60-room Dominican hotel, as the difference with the corresponding Cayacoa hotel exergy efficiency rate is more than $7 \%$.

Table 6. Energy and exergy efficiencies on an annual basis.

\begin{tabular}{|c|c|c|c|c|c|}
\hline & Symbol & Cayacoa & La Tambora & Rethymno & Kassandra \\
\hline Number Rooms & - & 295 & 60 & 140 & 500 \\
\hline $\begin{array}{l}\text { Electricity } \\
\text { (energy fraction) }\end{array}$ & $\mathrm{Fn}_{\text {electr }}$ & 0.908 & 0.147 & 0.749 & 0.892 \\
\hline $\begin{array}{l}\text { Diesel oil } \\
\text { (energy fraction) }\end{array}$ & $\mathrm{Fn}_{\text {Diesel }}$ & 0.092 & 0.853 & 0.251 & 0.108 \\
\hline Energy efficiency & $\mathrm{n}_{\text {overall }}$ & 0.562 & 0.549 & 0.559 & 0.562 \\
\hline $\begin{array}{l}\text { Electricity } \\
\text { (exergy fraction) }\end{array}$ & $\mathrm{Fx}_{\text {electr }}$ & 0.913 & 0.156 & 0.736 & 0.885 \\
\hline Diesel oil & $\mathrm{Fx}_{\text {Diesel }}$ & 0.087 & 0.844 & 0.264 & 0.115 \\
\hline
\end{tabular}


(exergy fraction)

$\begin{array}{llllll}\text { Exergy efficiency } & \psi_{\text {overall }} & 0.559 & 0.519 & 0.550 & 0.557\end{array}$

\section{Discussion}

This study investigated the overall efficiency of the processes and operations utilised in four hotels by employing exergy analysis and suggested as an essential framework to be used additionally to energy analysis. The results supported the importance of performing exergy efficiency analysis at system level along with energy analysis to reveal the holistic energy performance of lodgings, ratifying respective findings of previously published literature (Torio et al., 2009; Xydis et al., 2009). The findings extend previous limited evidence employing exergy efficiency analysis to evaluate the energy saving performance of hotels and assist environmentally conscious decision making (Szargut, 2005). Several important insights are offered regarding the added value of assessing the exergy flows of hotels' systems.

Concerning the role of location and associated weather conditions in the energy and exergy flows, this study does not indicate any particular effect of this parameter, since the results are not classified according to the location. This may be due to the similar seasonal mean values of the reference environment (i.e. average annual, as well as minimum and maximum monthly temperatures) in Samana, Crete and Chalkidiki. This is in congruence with Torio et al.'s (2009) recommendations regarding steady-state exergy analysis.

With regards to hotel classification, the 3-star hotels seem to have smaller absolute energy and exergy flows than the 5-star ones. However, normalisation of these flows on per room and operational period basis clearly show that energy and exergy consumption 
is not directly related to hotel rating classification (see Table 6). As a matter of fact, the estimation of normalised flows provides a clearer view of the hotels energy profiles, since the absolute flows do not offer a common basis for comparing hotels of different capacities. What is more, it is evident that assessing the energy and exergy flows reveal hotels' energy quality profiles to some extent only. In actuality, this study shows that the $3^{*}$ Rethymno hotel is the one with the lowest annual energy and exergy flows per room (19.85 and $20.28 \mathrm{GJ} /$ room, respectively) to cover corresponding needs in power. This could be attributed to the fact that operations in Rethymno hotel are restricted to one building only and services offered to guests are limited. However, the other $3 *$ hotel under study, namely La Tambora, demonstrates the highest exergy flow per room compared to the rest of hotels under examination, signifying that low energy and exergy flows may not relate to hotel classification. These results are in line with those of Stylos \& Vassiliadis (2015), who could not clearly link hotel rating to hoteliers' environmental management practices, although similar effects were found regarding financial and social responsibility practices. On the other hand, Wang (2012) and Wang and Huang (2013) found that hotel rating significantly and positively relates to annual energy consumption. In any case, focusing on the distinct operations involved in running each hotel, could potentially explain in depth the reasons for reaching these outcomes.

Taking a step further, this research clearly shows that low exergy flows do not necessarily relate to high exergy efficiencies, because exergy efficiency depends heavily on the type of energy mix utilised. The case of Rethymno hotel is representative of this implication, since the estimated exergy efficiency for this hotel is not the highest among all others in the study, although its exergy flows are the smallest. Taking one step further, although Kassandra hotel demonstrates only slightly lower exergy flow per room than La Tambora's respective figure, the exergy efficiency of systems at Kassandra hotel is one 
of the highest in the study. At the same time, the exergy efficiency at La Tambora hotel is the lowest, whereas the highest has been estimated for Cayacoa hotel operations. A combination of very high contribution of diesel oil to La Tambora's energy mix and, on the other hand, the extensive usage of electricity at Cayacoa hotel is the reason for this contrasting outcome. These findings are in line with those previously indicated by Torio et al. (2009) and Torio and Schmidt (2008) who articulate that the use of high exergy sources (e.g. fossil fuels), to mainly cover hotels' needs in heating, cooling and hot water production, renders low exergy efficiencies.

\subsection{Practical Implications and policy making}

The previous findings and theoretical implications may formulate the basis for the introduction of practical measures on behalf of the hoteliers at business level and policy making through specific directives at national or/and international level.

Hence, it would be beneficial for hotel resource management to include exergy efficiency estimations as a criterion for estimating hotel units' current energy quality profile and plan investments on active or passive energy systems accordingly. This would potentially contribute to creating an eco-friendlier hotel profile and, at the same time, achieve an effective energy usage.

From a wider perspective, advanced energy public policies could include an exergy efficiency indicator as a benchmarking criterion for a new generation of energy performance certificates (EPC) to be considered by policy makers. This would actually bring the focus onto the types of energy used and systems installed to run hotel operations, instead of just trying to achieve energy savings from any existing systems of low exergy capability. 
Therefore, the implementation of exergy efficiency analysis could create an effective energy mix from a holistic viewpoint. Planning at different levels, e.g. business unit/micro-level of hotels, and also wider at industry / macro-level, could enhance environmental protection by utilising energy sources of high exergy content. This would largely contribute to better targeting and achieving business objectives that would be in accordance with the national energy mix goals and the respective sustainable development strategies (Coronado Martínez et al., 2018).

In the same vein, it would be very beneficial to include hotel exergy efficiency as an additional indicator within the sustainability toolbox provided by the International Tourism Partnership (ITP), alongside the Hotel Water Measurement Initiative and the Hotel Carbon Measurement Initiative (International Tourism Partnership, 2018). This way the estimation and report of exergy flows and efficiencies would be made consistent and easy for hoteliers around the world to administer.

\section{Conclusions}

It is widely acknowledged that efficient energy usage in the hospitality industry is of utmost importance, especially for countries with an extensive tourism sector, due to high needs for power in running lodging operations (Chan and Lam, 2003; Teng et al., 2012; Vassallo et al., 2009). Natural resource conservation and energy usage efficiency, in particular, are crucial for the financial viability, environmental sustainability and societal responsibility of lodgings (Stylos and Vassiliadis, 2015). Yet lately researchers have suggested that exergy analysis should be performed along with energy analysis to allow for a comprehensive energy performance analysis of the systems under examination (Torio et al., 2009). Exergy analysis may reveal important managerial insights that go beyond cost minimisation of hotel operations. It is a tool that can support a fair 
quantification of hotels' overall energy profile, which may assist both engineers and hotel managers to improve environmental management decision making.

The current study draws on Xydis et al. (2009) and Gonclaves et al. (2012) and seeks to reveal the usefulness of estimating exergy flows and respective efficiency analyses. To overcome the geographical limitations of these studies and showcase the importance of examining the energy quality profile of hotels from a managerial viewpoint, the current one extends their line of thinking by conducting a series of comparative energy and exergy analyses between hotels located in the Dominican Republic and Greece. The premise is that comparisons between hotel sectors located in different geographical locations and different opening seasons could potentially result in interesting insights regarding the factors determining the energy consumption and environmental sustainability of lodgings (Bohdanowicz et al., 2011; Erdogan and Baris, 2007; Kumar, 2005). In both countries, the hospitality sector is a major part of the tourism industry, and thus, the energy consumption taking place in the lodgings should be thoroughly studied to improve the energy performance, minimise the consequences to the natural environment and improve managerial practice. This has been clearly articulated by Wang and Huang (2013) who call for an active hotel energy management that could shape robust marketing positioning strategies. At national level, a large part of the Dominican's Republic and Greece's needs in energy are imported in various forms (e.g. diesel oil, gas etc.) and, therefore, it is important to make best possible use of it by fostering nation-wide best practices (Yaw, 2005; Zografakis et al., 2011).

The execution of exergy analysis at hotel premises revealed its usefulness of performing comparisons between competitive establishments, and also the partial weakness of energy analysis to reveal the energy potential of the hotel processes in full. It was clearly shown from the estimation of energy and exergy efficiencies for the selected 
hotels that these two types of efficiency do not result in the same energy profile hotel ranking. This is due to the different amount of destruction of input exergy due to the diverse quantity of fossil fuels used (in this case diesel oil) to cover each hotel's needs in energy. This study ratifies the results of previously published literature that exergy efficiency is probably a more suitable measure of systems energy performance (Dewulf et al., 2008; Dincer, 2002; Gancolves et al., 2012; Xydis et al., 2009). Exergy efficiency analysis could lead to improved and more reliable monitoring and energy decision making, thus fostering hotels' sustainability agenda, e.g. within an Energy Balanced Scorecard managerial approach (Hoang and Rao, 2010). All four hotels implement various energy saving practices, which include the use of energy saving appliances, services and operations. Our main point here is not to showcase a direct comparison of the hotels for the sake of revealing which one is best from an environmental viewpoint since they are quite different in many ways - but rather demonstrate the difference in rankings that emerge when running exergy vs. energy analyses and estimating the corresponding efficiencies.

Taking one step further, with regards to hotels' ranking based on their energy and exergy flows and efficiency analyses, this study posits that the key qualifying parameter is the type of source used to cover respective energy needs. Hence, this research is in line with previous studies that suggest minimum possible use of fossil fuels to achieve a high energy quality and eco-friendly profile (Broman and Robèrt, 2017; Scheepens et al. 2016).

Furthermore, hotel location per se does not seem to play a significant role in ranking the hotels according to the efficiency of the energy and usable work potential, due to collecting data from tourism destinations where in general weather conditions are quite similar between March and October. As Wang (2012) posits, it is mainly the energy 
devices, energy efficiency-related tools and environmental practices employed in the organisation that determine a hotel's energy profile than external factors.

Hotel rating was also taken under consideration while setting up the case study of this research, as this factor has been reported to play an important role in hotel energy consumption (Lu et al., 2013; Priyadarsini et al. 2009). Although the energy and exergy flows did not indicate a specific pattern related to hotel rating, the energy and exergy efficiency analyses in this study revealed that the selected five-star hotels perform better than the three-star ones. This is attributed to the differences in the hotel energy mixes, with both five-star hotels making extensive use of electricity instead of diesel oil, in contrast to the practice of the three-star hotels. This is particularly evident from the exergy efficiency estimates of the hotels under investigation. The cleaner the energy forms utilised in covering hotels' energy needs, the higher the exergy efficiency, and thus the larger the energy content available to cover these needs. In fact, electricity is generally preferred in successfully adhering to this goal and that is why processes in most business sectors should be extensively equipped with highly efficient systems powered by this energy form. We ask for managers' particular attention on this, so they may take appropriate action and include exergy in evaluating the hotels' energy profiles (especially in case they take particular initiatives as part of a sustainability agenda).

Overall, this research revealed the usefulness of evaluating exergy flows along with energy ones and the corresponding efficiencies that could a) assist hotel administrations in their effort to better assess the use of energy resources, b) improve the environmental performance of the units they manage and c) build upon this enhanced energy assessment of the hotels to support their sustainability marketing strategy. This last one would be of particular interest to environmentally conscious guests, who tend to take the business and operations management practices of the hotels seriously when choosing lodging. 


\section{Limitations and future research directions}

As with any research, the present one has a number of limitations that could serve as the basis for future studies. A multiple case study approach was followed in performing comparative energy and exergy analyses. First, from a geographic point of view, this study compared hotel units located in countries of the Caribbean and Mediterranean seas, merely reflecting the 'sun and sand' type of tourism product; future studies could include lodgings located in rural and urban areas, as well as winter tourism destinations. Second, we have included three-star and five-star hotels in the comparative energy and exergy analyses in order to trace any hotel rating-dependent differences, and actually useful insights have been extracted. Nevertheless, not all hotel classification categories have been examined, and thus, it would be interesting to extend this research to one-star, twostar and four-star hotels, as well. Third, while hotels of diverse capacity and varied guest service ability have been incorporated into this study, we do not intend to generalise our findings as we cannot argue that all possible cases have been represented. Therefore, future research may include small boutique hotels, as well as big resorts in examining exergy efficiency and related impact. Fourth, electricity and diesel oil were included in our analysis, because these two energy forms are the ones utilised in the hotels under study. Future research may include hotels that make use of a more diverse energy mix. An energy analysis and respective efficiencies have been provided in addition to exergy equivalents to conclude about the use of energy and the actual energy profile of the hotels under study. Still, the primary forms of energy used for electricity production have not been included in this analysis. Thus, it would be very interesting to perform a similar analysis considering the primary energy carriers of electricity production (e.g. diesel, coal, photovoltaics, wind energy, hydropower?) and distribution. Therefore, an energy 
footprint analysis, taking under consideration the energy consumed in various life cycle stages would help produce a more complete view of hotels' energy profile, and it should be seriously considered in a future research study. That would broaden the assessment boundaries and deepen the analysis, potentially relating the hotel energy mixes to the quality of the national energy ones. Additionally, an analysis of the contribution of emissions and pollutants to air, water and soil in terms of chemical exergy for each substance would be useful to be made, in addition to including the exergy of system inputs, in a future research study as part of an Exergetic Life Cycle Assessment, as suggested in Koroneos \& Stylos (2014). Finally, although this study exemplifies the importance of exergy efficiency analysis in estimating the actual overall potential of energy systems installed in the hotels, more research is needed to formulate a robust set of practices that would enhance managers' relative decision making. A focus on specific activities and hotel equipment would reveal the activities that present the higher/lower exergy values and take proper measures. This would further contribute to the formation of integrated hotel energy systems that could optimise the relevant processes and minimise energy losses and wastes, thus leading to increased protection of the local natural environment (Simancas Cruz et al., 2018).

That being said, the set of four case studies utilised in this paper creates a diversified sample that helps us reach some meaningful conclusions. This sample is adequate to establish our main argument, i.e. managers should acknowledge that energy analysis alone is not enough to reach safe conclusions, because exergy (efficiency) analysis may create a different outlook of the hotels' energy profile, as these four case studies show.

Future research could also involve the development of computer software for assessing hotels' performance with respect to different climatic conditions, as well as considering various geometrical and dimensional characteristics of the lodgings. That 
would create a database and potentially a hotel exergy efficiency framework to be included as an additional indicator within ITP's sustainability toolbox. This could prove an invaluable source of information and serve as a useful tool for assisting hoteliers' decision-making process.

\section{References}

AlFaris, F., Abu-Hijleh, B., \& Abdul-Ameer, A. (2016). Using integrated control methodology to optimize energy performance for the guest rooms in UAE hospitality sector. Applied Thermal Engineering, 100, 1085-1094.

Ali, Y., Mairna, M., Shireen, A.-M., Mashal, K., \& Mohsen, M. (2008). Potential of energy savings in the hotel sector in Jordan. Energy Conversion and Management, 49, 3391-3397.

Becken, S., \& Patterson, M. (2006). Measuring national carbon dioxide emissions from tourism as a key step towards achieving sustainable tourism. Journal of Sustainable Tourism, 14(4), 323-338.

Bohdanowicz, P., \& Martinac, I. (2007). Determinants and benchmarking of resource consumption in hotels - Case study of Hilton International and Scandic in Europe. Energy and buildings, 39(1), 82-95.

Bohdanowicz, P., Zientara, P., \& Novotna, E. (2011). International hotel chains and environmental protection: an analysis of Hilton's we care! programme (Europe, 2006-2008). Journal of Sustainable Tourism, 19(7), 797-816.

Broman, G. I., \& Robèrt, K. H. (2017). A framework for strategic sustainable development. Journal of Cleaner Production, 140, 17-31. 
Carmona-Moreno, E., Céspedes-Lorente, J., \& De Burgos-Jiménez, J. (2004). Environmental strategies in Spanish hotels: contextual factors and performance. The Service Industries Journal, 24(3), 101-130.

Chan, W. W., \& Lam, J. C. (2003). Energy-saving supporting tourism sustainability: A case study of hotel swimming pool heat pump. Journal of Sustainable Tourism, 11(1), 74-83.

Choi, G., Parsa, H. G., Sigala, M., \& Putrevu, S. (2009). Consumers' environmental concerns and behaviors in the lodging industry: A comparison between Greece and the United States. Journal of Quality Assurance in Hospitality \& Tourism, 10(2), 93112.

Chow, T. T., Pei, G., Fong, K. F., Lin, Z., Chan, A. L. S., \& Ji, J. (2009). Energy and exergy analysis of photovoltaic-thermal collector with and without glass cover. Applied Energy, 86(3), 310-316.

Cipriano, M., \& Jafari, J. (2002). Sustainable hotels for sustainable destinations. Annals of Tourism Research, 29(1), 266-268.

Claver-Cortés, E., Molina-Azorín, J. F., Pereira-Moliner, J., \& López-Gamero, M. D. (2007). Environmental strategies and their impact on hotel performance. Journal of Sustainable Tourism, 15(6), 663-679.

Coronado Martínez, Y., Rosas Baños, M., \& Cerón Monroy, H. (2018). Ecotourism as a path to sustainable development in an isolated Magic Town: The case study of La Trampa, Mexico. Journal of Tourism Analysis: Revista de Análisis Turístico. https://doi.org/10.1108/JTA-02-2018-0004

Croes, R. R. (2006). A paradigm shift to a new strategy for small island economies: Embracing demand side economics for value enhancement and long term economic stability. Tourism Management, 27(3), 453-465. 
Dewulf, J., Van Langenhove, H., Muys, B., Bruers, S., Bakshi, B. R., Grubb, G. F., ... \& Sciubba, E. (2008). Exergy: its potential and limitations in environmental science and technology. Environmental Science \& Technology, 42(7), 2221-2232.

Dincer, I. (2002). The role of exergy in energy policy making. Energy Policy, 30(2), 137-149.

Dincer, I., Hussain, M. M., \& Al-Zaharnah, I. (2004). Energy and exergy use in public and private sector of Saudi Arabia. Energy Policy, 32(14), 1615-1624.

Dwyer, L., Edwards, D., Mistilis, N., Roman, C., \& Scott, N. (2009). Destination and enterprise management for a tourism future. Tourism Management, 30(1), 63-74.

El Dief, M., \& Font, X. (2012). Determinants of environmental management in the Red Sea hotels personal and organizational values and contextual variables. Journal of Hospitality \& Tourism Research, 36(1), 115-137.

Erdogan, N., \& Baris, E. (2007). Environmental protection programs and conservation practices of hotels in Ankara, Turkey. Tourism Management, 28(2), 604-614.

Filimonau, V., Dickinson, J., Robbins, D., \& Huijbregts, M. A. (2011). Reviewing the carbon footprint analysis of hotels: Life Cycle Energy Analysis (LCEA) as a holistic method for carbon impact appraisal of tourist accommodation. Journal of Cleaner Production, 19(17), 1917-1930.

Fotiadis, A. K., Vassiliadis, C. A., \& Rekleitis, P. D. (2013). Constraints and benefits of sustainable development: A case study based on the perceptions of small-hotel entrepreneurs in Greece. Anatolia, 24(2), 144-161.

Gikas, P., \& Tchobanoglous, G. (2009). Sustainable use of water in the Aegean Islands. Journal of Environmental Management, 90(8), 2601-2611. 
Goncalves, P., Gaspar, A. R., \& da Silva, M. G. (2012). Energy and exergy-based indicators for the energy performance assessment of a hotel building. Energy and Buildings, 52, 181-188.

Goodarzvand-Chegini, F., \& GhasemiKafrudi, E. (2017). Application of exergy analysis to improve the heat integration efficiency in a hydrocracking process, Energy and Environment, 28(5-6), 564-579.

Granovskii, M., Dincer, I., \& Rosen, M. A. (2008). Exergy and industrial ecology: an application to an integrated energy system. International Journal of Exergy, 5(1), 5263.

Hadjikakou, M., Chenoweth, J., Miller, G., Druckman, A., \& Li, G. (2014). Rethinking the economic contribution of tourism case study from a Mediterranean Island. Journal of Travel Research, 53(5), 610-624.

Hermann, W. A. (2006). Quantifying global exergy resources. Energy, 31(12), 16851702.

Hoang, V. N., \& Rao, D. P. (2010). Measuring and decomposing sustainable efficiency in agricultural production: A cumulative exergy balance approach. Ecological Economics, 69(9), 1765-1776.

Holiday Weather.Com (2017). Daily worldwide forecasts for your holiday. Retrieved: http:// http://www.holiday-weather.com.

Høyer, K. G. (2000). Sustainable tourism or sustainable mobility? The Norwegian case. Journal of Sustainable tourism, 8(2), 147-160.

Huang, K. T., Wang, J. C., \& Wang, Y. C. (2015). Analysis and benchmarking of greenhouse gas emissions of luxury hotels. International Journal of Hospitality Management, 51, 56-66. 
International Tourism Partnership (2018). Resources. Access via https://www.tourismpartnership.org/resources/ (last accessed on April 29, 2018).

Kharrazi, A., Kraines, S., Hoang, L., \& Yarime, M. (2014). Advancing quantification methods of sustainability: A critical examination emergy, exergy, ecological footprint, and ecological information-based approaches. Ecological Indicators, 37, $81-89$

Kirk, D. (1995). Environmental management in hotels. International Journal of Contemporary Hospitality Management, 7(6), 3-8.

Koroneos, C., \& Rovas, D. (2012). A review on exergy comparison of hydrogen production methods from renewable energy sources. Energy \& Environmental Science, 5(5), 6640-6651.

Koroneos, C., \& Stylos, N. (2014). Exergetic life cycle assessment of a grid-connected, polycrystalline silicon photovoltaic system. The International Journal of Life Cycle Assessment, 19(10), 1716-1732.

Kotas, T. J. (2013). The exergy method of thermal plant analysis. Elsevier.

Kozak, M., Rita, P., \& Bigné, E. (2018). New frontiers in tourism: destinations, resources, and managerial perspectives. European Journal of Management and Business Economics, 27(1), 2-5.

Kumar, S. (2005). Resource use and waste management in Vietnam hotel industry. Journal of Cleaner Production, 13(2), 109-116.

Law, A., De Lacy, T., Lipman, G., \& Jiang, M. (2016). Transitioning to a green economy: the case of tourism in Bali, Indonesia. Journal of Cleaner Production, 111, 295-305. 
Lu, S., Wei, S., Zhang, K., Kong, X., \& Wu, W. (2013). Investigation and analysis on the energy consumption of starred hotel buildings in Hainan Province, the tropical region of China. Energy Conversion and Management, 75, 570-580.

Mensah, I. (2006). Environmental management practices among hotels in the greater Accra region. International Journal of Hospitality Management, 25(3), 414-431.

Meyer, L., Tsatsaronis, G., Buchgeister, J., \& Schebek, L. (2009). Exergoenvironmental analysis for evaluation of the environmental impact of energy conversion systems. Energy, 34(1), 75-89.

Millar, M., Mayer, K. J., \& Baloglu, S. (2012). Importance of green hotel attributes to business and leisure travelers. Journal of Hospitality Marketing \& Management, 21(4), 395-413.

Oluseyi, P. O., Babatunde, O. M., \& Babatunde, O. A. (2016). Assessment of energy consumption and carbon footprint from the hotel sector within Lagos, Nigeria. Energy and Buildings, 118, 106-113.

Pappas, N. (2015). Achieving competitiveness in Greek accommodation establishments during recession. International Journal of Tourism Research, 17(4), 375-387.

Peralta-Ruiz, Y., González-Delgado, A. D., \& Kafarov, V. (2013). Evaluation of alternatives for microalgae oil extraction based on exergy analysis. Applied Energy, $101,226-236$.

Pérez-Pineda, F., Alcaraz, J. M., \& Colón, C. (2017). Creating sustainable value in the hospitality industry: a (critical) multi-stakeholder study in the Dominican Republic. Journal of Sustainable Tourism, 1-17.

Pirani, S. I., \& Arafat, H. A. (2014). Solid waste management in the hospitality industry: A review. Journal of Environmental Management, 146, 320-336. 
Pratt, S. (2015). The economic impact of tourism in SIDS. Annals of Tourism Research, $52,148-160$.

Priyadarsini, R., Xuchao, W., \& Eang, L. S. (2009). A study on energy performance of hotel buildings in Singapore. Energy and Buildings, 41(12), 1319-1324.

Pulido-Fernández, J. I., Andrades-Caldito, L., \& Sánchez-Rivero, M. (2015). Is sustainable tourism an obstacle to the economic performance of the tourism industry? Evidence from an international empirical study. Journal of Sustainable Tourism, 23(1), 47-64.

Romero, J. C., \& Linares, P. (2014). Exergy as a global energy sustainability indicator. A review of the state of the art. Renewable and Sustainable Energy Reviews, 33, 427442.

Saidur, R., Sattar, M. A., Masjuki, H. H., Ahmed, S., \& Hashim, U. (2007). An estimation of the energy and exergy efficiencies for the energy resources consumption in the transportation sector in Malaysia. Energy Policy, 35(8), 40184026 .

Scheepens, A. E., Vogtländer, J. G., \& Brezet, J. C. (2016). Two life cycle assessment (LCA) based methods to analyse and design complex (regional) circular economy systems. Case: Making water tourism more sustainable. Journal of Cleaner Production, 114, 257-268.

Simancas Cruz, M., García Cruz, J. I., Greifemberg, C. A., \& Peñarrubia Zaragoza, M. P. (2018). Strategies to improve the quality and competitiveness of coastal tourism areas: Applying tourism standards. Journal of Tourism Analysis: Revista de Análisis Turístico. https:// doi.org/10.1108/JTA-02-2018-0007

Slade, R., \& Bauen, A. (2013). Micro-algae cultivation for biofuels: cost, energy balance, environmental impacts and future prospects. Biomass and Bioenergy, 53, 29-38. 
Sohrabi, B., Vanani, I. R., Tahmasebipur, K., \& Fazli, S. (2012). An exploratory analysis of hotel selection factors: A comprehensive survey of Tehran hotels. International Journal of Hospitality Management, 31(1), 96-106.

Sørensen, F., \& Jensen, J. F. (2015). Value creation and knowledge development in tourism experience encounters. Tourism Management, 46, 336-346.

Stylos, N., \& Vassiliadis, C. (2015). Differences in Sustainable Management Between Four-and Five-Star Hotels Regarding the Perceptions of Three-Pillar Sustainability. Journal of Hospitality Marketing \& Management, 24(8), 791-825.

Szargut, J. (2005). Exergy Method-Technical and Ecological Applications, Renewable, 18, Wiley Interscience.

Tan, S. H., Habibullah, M. S., Tan, S. K., \& Choon, S. W. (2017). The impact of the dimensions of environmental performance on firm performance in travel and tourism industry. Journal of Environmental Management, 203(1), 603-611.

Tang, C. F., \& Tan, E. C. (2015). Does tourism effectively stimulate Malaysia's economic growth?. Tourism Management, 46, 158-163.

Teng, C. C., Horng, J. S., Hu, M. L. M., Chien, L. H., \& Shen, Y. C. (2012). Developing energy conservation and carbon reduction indicators for the hotel industry in Taiwan. International Journal of Hospitality Management, 31(1), 199-208.

Torio, H., Angelotti, A., \& Schmidt, D. (2009). Exergy analysis of renewable energybased climatisation systems for buildings: A critical view. Energy and Buildings, $41(3), 248-271$.

Torío, H., \& Schmidt, D. (2008). Exergetic assessment and contribution of solar energy systems to the energy performance of buildings. In Proceedings of the Nordic Symposium of Building Physics, (Vol. 2, pp. 637-644). 
Vassallo, P., Paoli, C., Tilley, D. R., \& Fabiano, M. (2009). Energy and resource basis of an Italian coastal resort region integrated using emergy synthesis. Journal of Environmental Management, 91(1), 277-289.

Wang, J. C. (2012). A study on the energy performance of hotel buildings in Taiwan. Energy and Buildings, 49, 268-275.

Wang, J. C., \& Huang, K. T. (2013). Energy consumption characteristics of hotel's marketing preference for guests from regions perspective. Energy, 52, 173-184.

Xuchao, W., Priyadarsini, R., \& Eang, L. S. (2010). Benchmarking energy use and greenhouse gas emissions in Singapore's hotel industry. Energy Policy, 38(8), 45204527.

Xydis G., Koroneos C. \& Polyzakis A. (2009) Energy and exergy analysis of the Greek hotel sector: An application, Energy and Buildings, 402-406.

Yaw, F. (2005). Cleaner technologies for sustainable tourism: Caribbean case studies. Journal of Cleaner Production, 13(2), 117-134.

Zografakis, N., Gillas, K., Pollaki, A., Profylienou, M., Bounialetou, F., \& Tsagarakis, K. P. (2011). Assessment of practices and technologies of energy saving and renewable energy sources in hotels in Crete. Renewable Energy, 36(5), 1323-1328. 